\title{
Poor histological lesions in IgA nephropathy may be reflected in blood and urine peptide profiling
}

\author{
Fredzzia Graterol ${ }^{1 \dagger}$, Maribel Navarro-Muñoz ${ }^{1,2 \dagger}$, Meritxell Ibernon ${ }^{1 \dagger}$, Dolores López ${ }^{3}$, Maria-Isabel Troya',
} Vanessa Pérez ${ }^{1,2}$, Josep Bonet ${ }^{1,2}$ and Ramón Romero ${ }^{1,2^{*}}$

\begin{abstract}
Background: IgA nephropathy (IgAN) is the most common primary glomerulonephritis worldwide, leading to renal failure in 15\% to $40 \%$ of cases. IgAN is diagnosed by renal biopsy, an invasive method that is not risk-free. We used blood and urine peptide profiles as a noninvasive method of linking IgAN-associated changes with histological lesions by Oxford classification.

Methods: We prospectively studied 19 patients with biopsy-proven IgAN and 14 healthy subjects from 2006 to 2009, excluding subjects with crescentic glomerulonephritis and collecting clinical and biochemical data at the time of diagnosis and during follow-up (24 months). Histological lesions were evaluated by Oxford classification. Proteomic analysis was performed by combining magnetic bead (MB) technology and mass spectrometry (MALDITOF MS) to obtain peptide profiles. Doubling of serum creatinine was considered a variable of poor renal prognosis.

Results: We identified 55 peptides-13 in serum, 26 in plasma, and 16 in urine-that differentiated IgAN patients from healthy subjects. A significant association was noted between serum/plasma and urine peptides and histological findings_ie, tubulointerstitial damage, segmental glomerulosclerosis, and endocapillary injury. We also identified 3 peptides - corresponding to bradykinin, uromodulin, and alpha-1-antitrypsin — that were associated with severity of lesions, such as tubulointerstitial damage and segmental glomerulosclerosis. Moreover, blood peptides with $\mathrm{m} / \mathrm{z}$ 2953, 5337, 9287, and 9289 and urine peptides with $\mathrm{m} / \mathrm{z}$ 1769, 1898, 1913, 1945, $2491,2756,2977,3004,3389$, and 4752 correlated significantly with poor renal function.

Conclusions: In patients with IgAN, the use of noninvasive approaches, such as blood and urine proteomics, can provide valuable information beyond that of standard diagnostic techniques, allowing us to identify blood and urine peptide profiles that are associated with poor histological lesions in IgAN patients.
\end{abstract}

\section{Background}

IgA nephropathy (IgAN) is the most common primary glomerulonephritis worldwide and is a significant cause of renal disease, leading to end-stage renal disease (ESRD) in $15 \%$ to $40 \%$ of patients after $20-25$ years of follow-up [1]. For this reason, methods must be developed to make an early diagnosis. Several clinical risk factors, such as male gender, hypertension, increased serum

\footnotetext{
* Correspondence: ramon.romero@uab.es

${ }^{\dagger}$ Equal contributors

'Department of Nephrology, Germans Trias i Pujol Hospital, Universitat Autònoma de Barcelona, Esfera UAB, Carretera de Canyet, s/n 08916Badalona, Barcelona, Spain

${ }^{2}$ Health Sciences Research Institute "Germans Trias i Pujol", Universitat Autònoma de Barcelona, Esfera UAB, Carretera de Can Ruti, Camí de les Escoles, s/n, 08916-Badalona, Barcelona, Spain

Full list of author information is available at the end of the article
}

creatinine level, proteinuria $>1 \mathrm{~g} /$ day, and absence of hematuria, are associated with a poor prognosis [2]. Further, histopathological findings at the time of diagnosis, such as glomerulosclerosis and chronic tubulointerstitial damage, are also predictors of poor renal outcome [3-5].

A diagnosis of IgAN is biopsy-proven, based on pathological criteria that include the presence of diffuse mesangial IgA deposits by immunofluorescence. The Oxford classification is a recent histological classification system that is based on 4 scores: interstitial fibrosis/tubular atrophy (IFTA), segmental glomerulosclerosis, endocapillary hypercellularity, and mesangial hypercellularity [6,7]. This new assessment has demonstrated that each variable correlates with clinical outcome $[8,9]$.

\section{Biomed Central}

(c) 2013 Graterol et al.; licensee BioMed Central Ltd. This is an Open Access article distributed under the terms of the Creative Commons Attribution License (http://creativecommons.org/licenses/by/2.0), which permits unrestricted use, distribution, and reproduction in any medium, provided the original work is properly cited. 
In the past decade, proteomics has been applied extensively to various fields of medicine, including nephrology [10-15] - particularly in urine, because it can be obtained noninvasively, allowing one to identify glomerular kidney disease (GKD)-related markers [16-26]. Profiling methods are gaining popularity in the quest for new putative biomarkers for glomerular disorders [27-35]. Magnetic bead (MB)-based fractionation methods, coupled with MALDITOF MS, were introduced recently as a urinary peptide profiling strategy [36-38] and have emerged as a suitable platform for rapid, high-throughput analysis.

The main objective of our study was to identify peptide profiles in blood and urine that are associated with IgAN and its histological lesions.

\section{Methods}

\section{Study population}

This prospective study was performed between June 2006 and November 2009 in the Nephrology Department, Germans Trias i Pujol Hospital (Barcelona, Spain). All procedures were conducted per the Declaration of Helsinki of 1971, as revised in 2008. The Clinical Research Ethics Committee of Germans Trias i Pujol Hospital approved the study protocol, and all patients gave written informed consent to participate.

\section{Study procedures}

For inclusion, patients had to be aged older than 18 years; show clinical signs of renal disease, such as proteinuria with stable renal function or various degrees of renal failure and the presence of hematuria; and be indicated for renal biopsy. Only patients with primary IgAN were included. Patients with crescentic glomerulonephritis were excluded.

Healthy subjects were used as controls to establish a normal peptide profile.

\section{Measurement of clinical and biochemical parameters}

The following clinical data were collected at the time of diagnosis: age, gender, history of hypertension, diabetes mellitus, and dyslipidemia. Biochemical data were collected at the time of study and after 2 years of follow-up: serum levels of creatinine, uric acid, albumin, and cholesterol; and proteinuria. Statin therapy and antihypertensive treatments that were based on renin-angiotensinaldosterone system (RAAS)-blocking drugs, such as angiotensin-converting enzyme inhibitors (ACEI) and angiotensin II receptor blockers (ARB), were recorded (Table 1).

\section{Renal biopsy}

Percutaneous renal biopsies were performed and processed routinely for light, immunofluorescence, and electron microscopy per standard procedures.

Light microscopy sections were stained with hematoxylin/eosin, Schiff's periodic acid, methenamine silver, Masson trichrome, and Congo red.

At the time of the biopsy, a single pathologist reviewed all renal biopsy slides and scored the pathological variables per the Oxford classification as follows:

Table 1 Demographic, clinical, and biochemical data of IgAN patients

\begin{tabular}{|c|c|c|}
\hline & \multicolumn{2}{|c|}{ IgAN patients } \\
\hline & At the time of initial biopsy & At the end of follow-up \\
\hline Number of patients & & \\
\hline Age, years & $42(33-52)$ & $44(35-54)$ \\
\hline Gender (Male), n (\%) & & \\
\hline Hypertension (Yes), n (\%) & & \\
\hline Diabetes (Yes), n (\%) & & \\
\hline Dyslipidemia (Yes), n (\%) & & \\
\hline Serum creatinine, mg/dl & $2.00(1.40-2.57)$ & $3.16^{a}(1.26-6.18)$ \\
\hline Uric acid, mg/dl & $7.40(5.45-8.30)$ & $7.40(6.55-9.20)$ \\
\hline Serum albumin, g/l & $34.00(31.00-39.00)$ & $40.00^{a}(36.75-42.40)$ \\
\hline Cholesterol, mg/dl & $194.00(157.00-221.75)$ & $147.00^{\mathrm{a}}(131.50-213.00)$ \\
\hline Proteinuria, g/24 hours & $2.28(1.20-4.26)$ & $1.30(0.52-3.27)$ \\
\hline RAAS blockade (Yes), n (\%) & $7(37)$ & $17(89)$ \\
\hline ACEl & $5(26)$ & $11(58)$ \\
\hline ARB & $1(5)$ & $3(16)$ \\
\hline ACEl plus ARB & $1(5)$ & $3(16)$ \\
\hline Statins (Yes), n (\%) & $4(21)$ & $9(47)$ \\
\hline
\end{tabular}

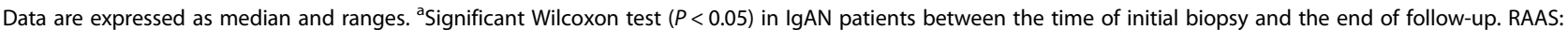
renin-angiotensin-aldosterone system; ACEl: angiotensin-converting enzyme inhibitors; ARB: angiotensin II receptor blockers. 
IFTA $\leq 25 \%$ (T0), $26 \%$ to $50 \%$ (T1) or $>50 \%$ (T2); segmental glomerulosclerosis absent (S0) or present (S1); endocapillary hypercellularity absent (E0) or present (E1); and mesangial hypercellularity $\leq 0.5$ (M0) or $>0.5$ (M1) [6].

\section{Blood samples}

Blood samples were collected from the participants on the same day that the renal biopsy was performed. Serum and plasma-EDTA samples were obtained by centrifugation at $2200 \mathrm{~g}$ for $10 \mathrm{~min}$, aliquoted to avoid freeze-thaw cycles, and stored at $-80^{\circ} \mathrm{C}$ until use.

\section{Urine samples}

Fresh, first-morning urine samples were collected from the participants on the same day that the renal biopsy was performed. Briefly, urine samples were centrifuged at $2100 \mathrm{~g}$ for $30 \mathrm{~min}$ at $4^{\circ} \mathrm{C}$ to remove particulate material and cellular debris. The supernatant was adjusted to $6.5 \mathrm{pH}$ with $\mathrm{NH}_{4} \mathrm{HCO}_{3}(1 \mathrm{M})$ to minimize precipitation during storage, aliquoted to avoid freeze-thaw cycles, and stored at $-80^{\circ} \mathrm{C}$ until use [36]. Protease inhibitors were not added. Normalization of the samples to urinary protein concentration was not necessary to analyze peptide profiles [38].

\section{Peptide enrichment and identification by MALDI-TOF MS analysis}

Peptides in serum and plasma $(80 \mu \mathrm{l})$ and urine supernatant $(110 \mu \mathrm{l})$ were extracted using MB. The profiling kit that we used to analyze blood samples was the MB-IMAC $\mathrm{Cu}$ kit (Bruker Daltonics, Bremen, Germany), which is based on the affinity of peptides to immobilized copper ions on the surface of MB. In the urine samples, the beads that we used were coated with $\mathrm{C} 18$ aliphatic chains, wherein peptides were captured by hydrophobic interactions (Dynabeads ${ }^{\circledR}$ RP-C18, Invitrogen, the Netherlands).

Each serum, plasma, and urine sample was processed in duplicate, and each duplicate was spotted twice on the MALDI target (AnchorChip 600/384, Bruker Daltonics). Thus, 4 MALDI spectra were obtained for each sample, acquired for $\mathrm{m} / z$ values from 1000 to 10,000. ClinProTools (v2.0; Bruker Daltonics) was used to analyze peptide profiles, subtract baseline values, and normalize the spectra. Further details on the MALDI-TOF MS analysis are described in our previous report $[38,39]$.

\section{Statistical analysis}

Normality of the variables was assessed by KolmogorovSmirnov test. Continuous variables were expressed as median and range and were compared by Mann-Whitney $U$-test or Kruskal-Wallis test, as appropriate. Wilcoxon test was performed for paired samples as required to assess differences at the end of follow-up. Categorical variables were analyzed using chi-square or Fisher's exact probability test. Associations between variables were assessed using the Spearman correlation coefficient.

Statistical analyses were performed using SPSS, v15.0 (SPSS Inc., Chicago, IL). A two-tailed $p$-value of $<0.05$ was considered to be statistically significant.

\section{Results}

\section{Patients}

Nineteen IgAN patients were enrolled, and 14 healthy subjects were included in the study as controls. The baseline clinical and biochemical characteristics of the IgAN patients are summarized in Table 1 . Healthy subjects ranged in age from 26 to 41 years (median 30 years); 6 were male (43\%). The entire control group had normal renal function without hematuria or proteinuria, and none was treated.

Significant differences were observed between IgAN patients and healthy subjects with regard to age and renal function but not gender. Also, we compared clinical and biochemical variables at the time of biopsy with those at the end of the follow-up (24 months) (Table 1). During the follow-up, 5 patients (26.3\%) with impaired serum creatinine doubled their serum creatinine levels. In contrast, proteinuria levels fell, albeit insignificantly. Further, serum cholesterol and serum albumin levels differed significantly between baseline and at the end of the follow-up.

\section{Identification of IgAN-related peptides in blood and urine} The blood and urinary peptide profiles of IgAN patients differed significantly from those of healthy subjects; using Clinprotools, we obtained 13 differential peaks in serum, 26 in plasma, and 16 in urine that discriminated IgAN patients from healthy subjects and achieved statistical significance (Additional file 1). Two peaks in plasma and 6 peaks in urine were identified in our earlier reports $[38,39]$.

Our results suggest that peptides that were detected in plasma by MALDI-TOF at $m / z=1063$ and $m / z=1898$ correspond to bradykinin (KNG1) and complement factor C4 (C4A), respectively [39]. Similarly, peptides that were detected in urine by MALDI-TOF at $m / z=1898$ and 1913 corresponded to uromodulin peptides (UMOD); those at $m / z=1945,2392$, and 2505 corresponded to alpha-1antitrypsin peptides (A1AT); and that at $m / z=2714$ corresponded to beta-2-microglobulin (B2M) [38].

\section{Association between IgAN-related peptides and histological lesions by Oxford classification}

The histological lesions of the IgAN patients are summarized in Table 2. 
Table 2 Scores of histological lesions by Oxford classification in IgAN patients

\begin{tabular}{cc}
\hline Histological lesions & IgAN patients \\
\hline IFTA, $n(\%)$ & \\
\hline T0 & $6(32)$ \\
\hline T1 & $8(42)$ \\
\hline S2 & $5(26)$ \\
\hline S0 & $3(16)$ \\
\hline Sndocapillary hypercellularity, $\mathrm{n}(\%)$ & $16(84)$ \\
\hline E0 & $12(63)$ \\
\hline E1 & $7(37)$ \\
\hline Mesangial hypercellularity, $\mathrm{n}(\%)$ & $0(0)$ \\
\hline M0 & $19(100)$ \\
\hline M1
\end{tabular}

Interstitial fibrosis/tubular atrophy (IFTA).

The blood and urine peptides of IgAN patients were associated with IFTA lesions (Additional file 2). In evaluating tubulointerstitial damage T2 $(>50 \%)$ in patients with IgAN, we noted that serum peptides at $\mathrm{m} / z 5966$ and 9289 increased in peak area compared with the other 2 groups (T0, T1). Moreover, serum peptides at $m / z$ 1466, 1617, 3193, 3264, 5337, 5889, and 5905 increased in peak area with respect to T1.

Similarly, plasma peptides at $m / z 2661$ and 2790 rose in peak area versus the other 2 groups (T0, T1), but plasma peptides at $m / z 1063$ and 1078 decreased in peak area in IgAN patients with tubulointerstitial damage T2 compared with subjects with T0 and T1.

In urine, peptides at $m / z 1945$ and 2491 increased in peak area in IgAN patients with T2 tubulointerstitial damage $(>50 \%)$, but peptides at $m / z 1769,1898,2977$, $3004,3389,3406,4658$, and 4752 fell compared with the T0 and T1 groups. Further, as shown in Figure 1a-c, bradykinin peptide $(\mathrm{m} / z$ 1063) and UMOD peptide $(\mathrm{m} / z$ 1898) decreased in parallel with the progression of tubulointerstitial damage. But, A1AT peptide increased proportionally to tubulointerstitial damage.

As shown in Figure $2 \mathrm{a}-\mathrm{d}$, urine peptides at $\mathrm{m} / \mathrm{z}$ 1945,2392 , and 4013 increased in peak area in IgAN patients with $\mathrm{S} 1$ lesions, but the peptide at $\mathrm{m} / z 3389$ fell in peak area compared with IgAN patients with S0 lesions. No associations were observed between segmental glomerulosclerosis and blood peptides.

A lack of endocapillary hypercellularity (E0) was associated with increased peak areas of peptides at $m / z 1546$ and 3264, but the $m / z 3242$ peptide declined in peak area in the serum of IgAN patients (Figure 3a-c). Moreover, E0 correlated with decreased peak area of peptides at $m / z 3242$ and $m / z 8602$ in the plasma of IgAN patients compared with endocapillary hypercellularity (E1) (Figure 4a-b). No associations were observed in the urine peptides.

No associations were observed between blood or urine peptides and mesangial hypercellularity in IgAN patients.

\section{Association between peptides and doubling of serum creatinine in IgAN}

Serum peptides at $m / z 2953,5337$, and 9289 and plasma peptides at $m / z 9287$ were linked with the doubling of serum creatinine in IgAN patients. Also, urine peptides at $m / z 1769,1898,1913,1945,2491,2756,2977,3004$, 3389 , and 4752 correlated with poor creatinine levels in IgAN patients (Table 3).

\section{Association between peptides and clinical parameters}

Urinary UMOD-derived peptides $(m / z$ 1898, 1913) correlated inversely between baseline serum creatinine, and $m / z 1913$ also correlated inversely with proteinuria. Urinary A1AT-derived peptides $(m / z$ 1945, 2392 and 2505) showed a positive association with proteinuria. Also, $\mathrm{m} / \mathrm{z}$ 1945 showed a positive correlation with serum creatinine.

Most patients had varying degrees of hematuria at diagnosis; thus, it was not possible to compare the influence of hematuria on peptide profile changes.
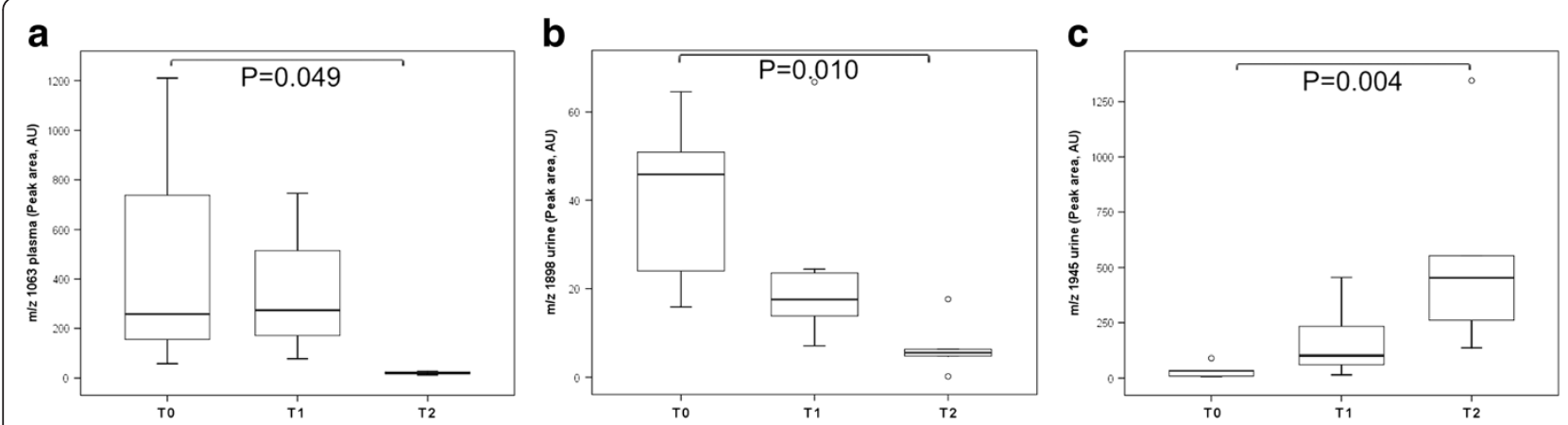

Figure 1 Differential expression of bradykinin, uromodulin, and alpha-1-antytripsin peptides by interstitial fibrosis/tubular atrophy (IFTA) lesion. Box plot of differential plasma expression of $\mathrm{m} / \mathrm{z} 1063$ (a) and urine expression of $\mathrm{m} / \mathrm{z} 1898$ (b) and $\mathrm{m} / \mathrm{z} 1945$ (c) in lgAN patients without (T0) or with $(\mathrm{T} 1, \mathrm{~T} 2)$ interstitial fibrosis/tubular atrophy (IFTA) lesions. Outliers are open circles. AU = Arbitrary units. 


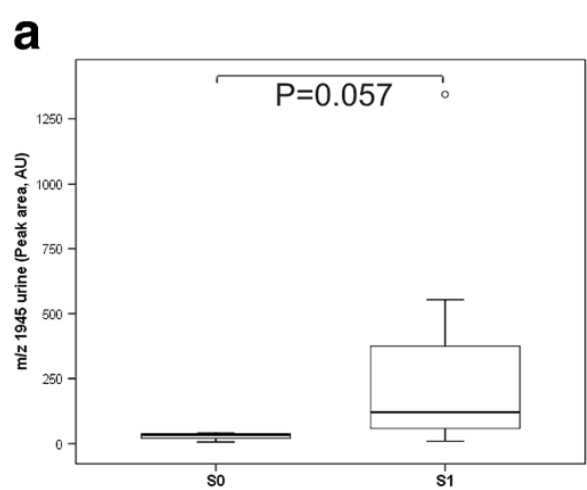

b

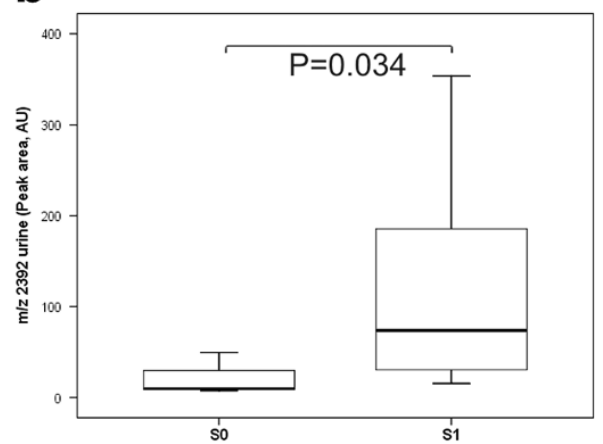

C

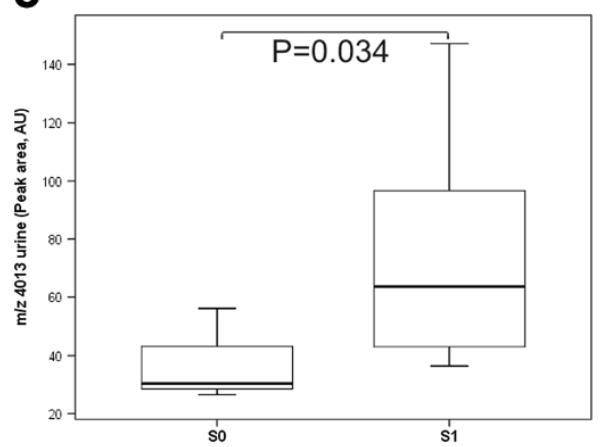

d

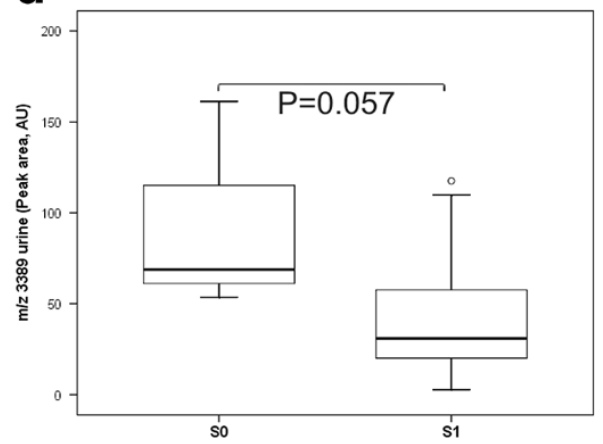

Figure 2 Differentially expressed peptide peaks in urine by segmental glomerulosclerosis lesion. Box plot of differential urine expression of $m / z 1945$ (a), m/z 2392 (b), m/z 4013 (c), and m/z 3389 (d) in lgAN patients without (S0) or with (S1) segmental glomerulosclerosis lesions. Outliers are open circles. $\mathrm{AU}=$ Arbitrary units.

\section{Discussion}

In this preliminary prospective study, peptide patterns in blood and urine were observed in patients with IgAN that allowed us to differentiate them from healthy subjects. Bradykinin peptide and a fragment of complement C4a were identified in blood samples, as were UMOD, A1AT, and B2-microglobulin peptides in urine. Moreover, these peptides were associated with poor histological lesions in IgAN patients, particularly with tubulointerstitial damage and segmental glomerulosclerosis.
In IgAN, much effort has been aimed to correlate a wide range of histological lesions with clinical outcome. In this report, we used the Oxford classification to explore IgANassociated changes from blood and urine peptide profiles, because it is the most recent pathological classification system and was developed as a reproducible method of predicting the risk of disease progression with regard to clinical outcome and histological lesions.

Recently, new methods have been described to identify biological biomarkers in various fluids using proteomic

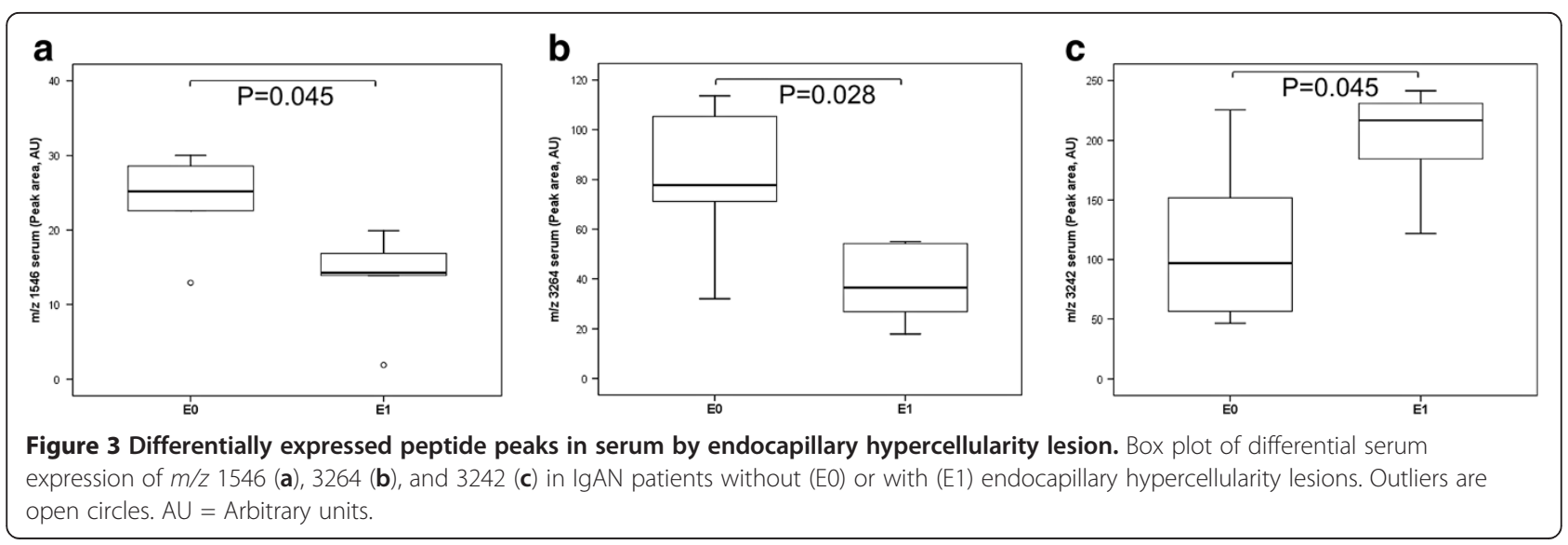



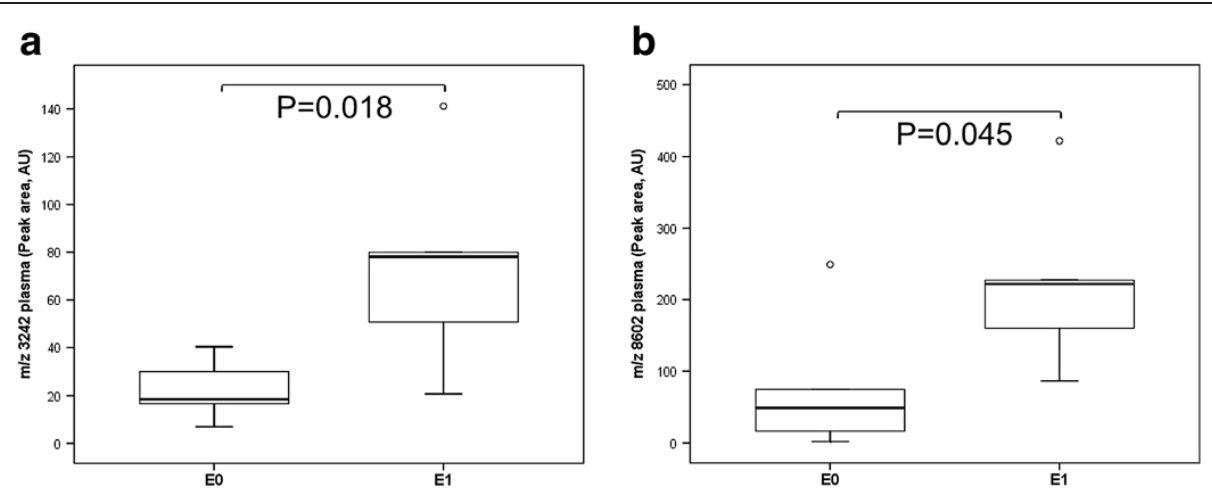

Figure 4 Differentially expressed peptide peaks in plasma by endocapillary hypercellularity lesion. Box plot of differential plasma expression of $\mathrm{m} / \mathrm{z} 3242$ (a) and $\mathrm{m} / \mathrm{z} 8602$ (b) in IgAN patients without (E0) or with (E1) endocapillary hypercellularity lesions. Outliers are open circles.

techniques. In our previous report [38], we demonstrated that MB-based profiling and MALDI-TOF MS identify disparities in urine between GKD patients and controls, suggesting that establishment of a differential peptide profile is the initial step toward classifying GKD. In the current study, the majority of peptides, specifically high levels of an A1AT-derived peptide $(\mathrm{m} / z$ 1945) and low levels of a UMOD-derived peptide $(\mathrm{m} / \mathrm{z} 1898)$ and bradykinin $(m / z$ 1063), was linked to tubulointerstitial damage.

Alpha-1-antitrypsin protects the extracellular matrix from neutrophil attack through its anti-inflammatory and anti-apoptotic effects. Kwak et al. [40] reported increased levels of A1AT peptides in kidney tissue and urine in IgAN patients compared with healthy subjects. The authors speculated that renal tubular epithelial cells produce A1AT in response to tubulointerstitial damage. Consistently, our results reinforce the suggestion that high levels of A1AT in urine might constitute a response

Table 3 Relationship between doubling of serum creatinine and peptide peaks

\begin{tabular}{lccc}
\hline Biofluid & Peptides $(\mathbf{m} / \mathbf{z})$ & $\mathbf{R}$ & $\mathbf{p}^{*}$ \\
\hline Serum & 2953 & 0.624 & 0.040 \\
\cline { 2 - 4 } & 5337 & -0.615 & 0.044 \\
\cline { 2 - 4 } & 9289 & 0.711 & 0.014 \\
\hline Plasma & 9287 & 0.615 & 0.044 \\
\hline Urine & 1769 & -0.718 & 0.001 \\
\cline { 2 - 4 } & 1898 & -0.734 & $<0.001$ \\
\cline { 2 - 4 } & 1913 & -0.598 & 0.007 \\
\cline { 2 - 4 } & 1945 & 0.603 & 0.006 \\
\cline { 2 - 4 } & 2491 & 0.465 & 0.045 \\
\cline { 2 - 4 } & 2756 & -0.443 & 0.058 \\
\cline { 2 - 4 } & 2977 & -0.564 & 0.012 \\
\cline { 2 - 4 } & 3004 & -0.631 & 0.004 \\
\cline { 2 - 4 } & 3389 & -0.529 & 0.020 \\
\hline
\end{tabular}

to the inflammatory process in GKD. Likewise A1AT has a function in tubulointerstitial injury; we noted an inverse association between UMOD-derived peptides and tubulointerstitial lesions, consistent with other groups that have described low urinary UMOD levels in association with tubular atrophy and interstitial infiltration in renal biopsies [41].

Uromodulin is a glycoprotein that is expressed on renal tubular epithelial cells and is the most abundant protein in urine. Recent studies have implicated UMOD in chronic kidney disease [41-43]. In a previous report, we observed an inverse correlation between UMOD peptides, serum creatinine, and proteinuria in patients with GKD [38].

Further, in IgAN, Wu et al. [37] described a urine peptide profile, noting downregulation of peptide that corresponded to UMOD, allowing them to discriminate IgAN from healthy subjects. In the current study, our peptide profile could be a biomarker of histological lesions but is not specific for IgAN.

Rocchetti et al. [23] reported a significant decrease in the urinary excretion of kininogen in IgAN patients, particularly in unresponsive ACEI therapy patients. The authors speculated that this difference reflects the severity of renal damage in IgAN patients. Similarly, we found a decreased in kininogen-derived peptide bradykinin $(m / z 1063)$ in plasma from IgAN patients with severe tubulointerstitial damage T2. But, we could not demonstrate this effect because most patients did not receive ACEI or ARB agents at baseline. Thus, we could not compare the effects of these drugs on peptide profiles.

Bradykinin is a nonapeptide that is derived from the kininogen protein, a robust agonist of the bradykinin 2 receptor, enhancing the production of nitric oxide and prostaglandins. Potent renal vasodilator, antithrombotic and antifibrotic effects of kinins have been observed recently in diabetic nephropathy [44]. Furthermore, upregulation of bradykinin receptor has 
been described to mediate the progression of focal segmental glomerulosclerosis [45].

In a previous report, Kang et al. [9] observed that segmental glomerulosclerosis and IFTA reflect chronic damage, which can be used to predict the long-term prognosis of patients with IgAN. Our findings suggest that a rise in peptides at $m / z$ 1945, 2392, and 4013 and a decline in the peptide at $\mathrm{m} / z 3389$ observed in patients with $\mathrm{S} 1$ reflect chronic glomerular injury.

Endocapillary and mesangial hypercellularity lesions were not associated with renal outcome in the original Oxford cohorts, although few reports have reported such findings. In our study, we identified 5 peptides-in serum at $\mathrm{m} / z 1546,3264$, and 3242 and in plasma at $\mathrm{m} / \mathrm{z}$ 3242 , 8602-of which the plasma and serum peptides at $\mathrm{m} / z 3242$ and plasma peptide at $\mathrm{m} / z 8602$ increased and serum peptides at $m / z 1546$ and 3264 decreased in the presence of endocapillary hypercellularity.

Further, many IgAN patients showed mesangial hypercellularity-this score is defined as the number of mesangial cells per mesangial area. Previous studies have shown that mesangial hypercellularity correlates with an active lesion; perhaps patients with M1 have a good response to treatment.

A limitation of this study is that we could not confirm that peptides of bradykinin, UMOD and A1AT are related specifically to IgAN, because our population was in various stages of kidney disease and degrees of interstitial injury. Interestingly, we found a relationship between peptide profiles in the serum, plasma, and urine of IgAN patients with the doubling of serum creatinine levels-particularly, in the urine samples with UMOD and A1AT peptides. Based on these findings, we propose that this peptide profile is a potential biomarker predictor of renal outcome, but we can not exclude the possibility that these peptides constitute a biomarker of chronic kidney diseases. It is necessary to expand this population study to other types of GKD to mitigate the limitations on its reproducibility and thus obtain a specific peptide profile.

Similarly, our patients had mesangial hypercellularity, and all were classified as M1. This feature of our study population did not allow us to evaluate the influence of this injury on peptide profiles. Finally, identifying peptides in biological fluids is critical in determining their function in the disease process.

\section{Conclusions}

IgAN is a glomerular disease, the pathogenic mechanism of which remains unknown. Proteomic analysis allows us to obtain a peptide profile that can enhance the diagnosis and prognosis of this glomerular disease. Further studies with more patients are needed to determine the function of bradykinin, UMOD, and A1AT peptides in the pathogenesis of IgAN.

\section{Additional files}

Additional file 1: Differentially expressed peptide peaks between IgAN patients and healthy subjects.

Additional file 2: Differentially expressed peptide peaks by interstitial fibrosis/tubular atrophy (IFTA) lesion.

\section{Competing interests}

The authors declare no potential conflicts of interest with respect to the authorship or publication of this article. The results presented in this paper have not been published previously in whole or in part, except in abstract format.

\section{Authors' contributions}

FG: participated in the conception and design of the study, carried out the collection of samples, clinical data management, statistical analysis and involved in drafting the manuscript and revising it critically for important intellectual content. MNM: participated in the conception and design of the study, carried out the collection of samples, analysis and interpretation of proteomic data, statistical analysis and involved in drafting the manuscript and revising it critically for important intellectual content. Ml: participated in the conception and design of the study, carried out the collection of samples, clinical data management, statistical analysis and involved in drafting the manuscript and revising it critically for important intellectual content. DL: carried out the histological analysis. MIT: helped to perform the statistical analysis. VP: participated in the collection of samples. JB: involved in revising the manuscript critically for important intellectual content and has given final approval of the version to be published. RR: made substantial contributions to conception and design, involved in revising the manuscript critically for important intellectual content and has given final approval of the version to be published. All authors read and approved the final manuscript.

\section{Acknowledgments}

This work was supported by grants from Fondo de Investigación Sanitaria (FIS, PI06/0878) and Instituto de Salud Carlos III (ISCIII-RETICS REDinREN RD 06/0016), Spain. This work was presented as a Free Oral Communication at the $49^{\text {th }}$ ERA-EDTA Congress, May 24-27, 2012 in Paris, France.

\section{Author details}

'Department of Nephrology, Germans Trias i Pujol Hospital, Universitat Autònoma de Barcelona, Esfera UAB, Carretera de Canyet, s/n 08916Badalona, Barcelona, Spain. ${ }^{2}$ Health Sciences Research Institute "Germans Trias i Pujol", Universitat Autònoma de Barcelona, Esfera UAB, Carretera de Can Ruti, Camí de les Escoles, s/n, 08916-Badalona, Barcelona, Spain. ${ }^{3}$ Departament of Pathology, Germans Trias i Pujol Hospital, Universitat Autònoma de Barcelona, Esfera UAB, Carretera de Canyet, s/n 08916Badalona, Barcelona, Spain.

Received: 6 November 2012 Accepted: 5 April 2013

Published: 11 April 2013

\section{References}

1. Barratt J, Feehally J: IgA nephropathy. J Am Soc Nephrol 2005 16(7):2088-2097

2. Frimat L, Briancon S, Hestin D, Aymard B, Renoult E, Huu TC, Kessler M: IgA nephropathy: prognostic classification of end-stage renal failure. L'Association des Nephrologues de l'Est. Nephrol Dial Transplant 1997, 12(12):2569-2575.

3. D'Amico G: Natural history of idiopathic IgA nephropathy: role of clinical and histological prognostic factors. Am J Kidney Dis 2000, 36(2):227-237.

4. Daniel L, Saingra Y, Giorgi R, Bouvier C, Pellissier JF, Berland Y: Tubular lesions determine prognosis of IgA nephropathy. Am J Kidney Dis 2000, 35(1):13-20 
5. Myllymaki JM, Honkanen TT, Syrjanen JT, Helin HJ, Rantala IS, Pasternack Al, Mustonen JT: Severity of tubulointerstitial inflammation and prognosis in immunoglobulin A nephropathy. Kidney Int 2007, 71(4):343-348.

6. Cattran DC, Coppo R, Cook HT, Feehally J, Roberts IS, Troyanov S, Alpers CE, Amore A, Barratt J, Berthoux F, Bonsib S, Bruijn JA, D'Agati V, D'Amico G, Emancipator S, Emma F, Ferrario F, Fervenza FC, Florquin S, Fogo A, Geddes CC, Groene HJ, Haas M, Herzenberg AM, Hill PA, Hogg RJ, Hsu SI, Jennette JC, Joh K, Julian BA, Kawamura T, Lai FM, Leung CB, Li LS, Li PK, Liu ZH, Mackinnon B, Mezzano S, Schena FP, Tomino Y, Walker PD, Wang H, Weening JJ, Yoshikawa N, Zhang H: The Oxford classification of IgA nephropathy: rationale, clinicopathological correlations, and classification. Kidney Int 2009, 76(5):534-545.

7. Roberts IS, Cook HT, Troyanov S, Alpers CE, Amore A, Barratt J, Berthoux F, Bonsib S, Bruijn JA, Cattran DC, Coppo R, D'Agati V, D'Amico G, Emancipator S, Emma F, Feehally J, Ferrario F, Fervenza FC, Florquin S, Fogo A, Geddes CC, Groene HJ, Haas M, Herzenberg AM, Hill PA, Hogg RJ, Hsu SI, Jennette JC, Joh K, Julian BA, Kawamura T, Lai FM, Li LS, Li PK, Liu ZH, Mackinnon B, Mezzano S, Schena FP, Tomino Y, Walker PD, Wang H, Weening JJ, Yoshikawa N, Zhang $\mathrm{H}$ : The Oxford classification of IgA nephropathy: pathology definitions, correlations, and reproducibility. Kidney Int 2009, 76(5):546-556.

8. Coppo R, Troyanov S, Camilla R, Hogg RJ, Cattran DC, Cook HT, Feehally J, Roberts IS, Amore A, Alpers CE, Barratt J, Berthoux F, Bonsib S, Bruijn JA, D'Agati V, D'Amico G, Emancipator SN, Emma F, Ferrario F, Fervenza FC, Florquin S, Fogo AB, Geddes CC, Groene HJ, Haas M, Herzenberg AM, Hill PA, Hsu SI, Jennette JC, Joh K, Julian BA, Kawamura T, Lai FM, Li LS, Li PK, Liu ZH, Mezzano S, Schena FP, Tomino Y, Walker PD, Wang H, Weening JJ, Yoshikawa N, Zhang $\mathrm{H}$ : The Oxford IgA nephropathy clinicopathological classification is valid for children as well as adults. Kidney Int 2010 77(10):921-927.

9. Kang SH, Choi SR, Park HS, Lee JY, Sun IO, Hwang HS, Chung BH, Park CW, Yang CW, Kim YS, Choi YJ, Choi BS: The Oxford classification as a predictor of prognosis in patients with IgA nephropathy. Nephrol Dial Transplant 2012, 27(1):252-258.

10. Thongboonkerd $\mathrm{V}$ : Biomarker discovery in glomerular diseases using urinary proteomics. Proteomics Clin Appl 2008, 2(10-11):1413-1421.

11. Thongboonkerd V, Klein JB, Jevans AW, McLeish KR: Urinary proteomics and biomarker discovery for glomerular diseases. Contrib Nephrol 2004, 141:292-307.

12. Thongboonkerd V: Renal and Urinary Proteomics. Proteomics Clin Appl 2008, 2(7-8):947-949.

13. Niwa T: Biomarker discovery for kidney diseases by mass spectrometry. J Chromatogr B Analyt Technol Biomed Life Sci 2008, 870(2):148-153.

14. Barratt J, Topham P: Urine proteomics: the present and future of measuring urinary protein components in disease. CMAJ 2007 177(4):361-368.

15. Casado-Vela J, del Pulgar TG, Cebrian A, Alvarez-Ayerza N, Lacal JC: Human urine proteomics: building a list of human urine cancer biomarkers. Expert Rev Proteomics 2011, 8(3):347-360.

16. Park MR, Wang EH, Jin DC, Cha JH, Lee KH, Yang CW, Kang CS, Choi YJ: Establishment of a 2-D human urinary proteomic map in IgA nephropathy. Proteomics 2006, 6(3):1066-1076

17. Janech MG, Raymond JR, Arthur JM: Proteomics in renal research. Am J Physiol Renal Physiol 2007, 292(2):F501-F512.

18. Pang JX, Ginanni N, Dongre AR, Hefta SA, Opitek GJ: Biomarker discovery in urine by proteomics. J Proteome Res 2002, 1(2):161-169.

19. Candiano G, Musante L, Bruschi M, Petretto A, Santucci L, Del Boccio P, Pavone B, Perfumo F, Urbani A, Scolari F, Ghiggeri GM: Repetitive fragmentation products of albumin and alpha1-antitrypsin in glomerular diseases associated with nephrotic syndrome. J Am Soc Nephrol 2006, 17(11):3139-3148.

20. Hellin JL, Bech-Serra JJ, Moctezuma EL, Chocron S, Santin S, Madrid A, Vilalta R, Canals F, Torra R, Meseguer A, Nieto JL: Very low-molecular-mass fragments of albumin in the plasma of patients with focal segmental glomerulosclerosis. Am J Kidney Dis 2009, 54(5):871-880.

21. Magistroni R, Ligabue G, Lupo V, Furci L, Leonelli M, Manganelli L, Masellis M, Gatti V, Cavazzini F, Tizzanini W, Albertazzi A: Proteomic analysis of urine from proteinuric patients shows a proteolitic activity directed against albumin. Nephrol Dial Transplant 2009, 24(5):1672-1681.

22. Ngai HH, Sit WH, Jiang PP, Xu RJ, Wan JM, Thongboonkerd V: Serial changes in urinary proteome profile of membranous nephropathy: implications for pathophysiology and biomarker discovery. J Proteome Res 2006, 5(11):3038-3047.

23. Rocchetti MT, Centra M, Papale M, Bortone G, Palermo C, Centonze D, Ranieri E, Di Paolo S, Gesualdo L: Urine protein profile of IgA nephropathy patients may predict the response to ACE-inhibitor therapy. Proteomics 2008, 8(1):206-216.

24. Shui HA, Huang TH, Ka SM, Chen PH, Lin YF, Chen A: Urinary proteome and potential biomarkers associated with serial pathogenesis steps of focal segmental glomerulosclerosis. Nephrol Dial Transplant 2008, 23(1):176-185.

25. Varghese SA, Powell TB, Budisavljevic MN, Oates JC, Raymond JR, Almeida JS, Arthur JM: Urine biomarkers predict the cause of glomerular disease. J Am Soc Nephrol 2007, 18(3):913-922.

26. Yokota H, Hiramoto M, Okada H, Kanno Y, Yuri M, Morita S, Naitou M, Ichikawa A, Katoh M, Suzuki H: Absence of increased alpha1microglobulin in IgA nephropathy proteinuria. Mol Cell Proteomics 2007, 6(4):738-744.

27. Vanhoutte KJ, Laarakkers C, Marchiori E, Pickkers P, Wetzels JF, Willems JL, van den Heuvel LP, Russel FG, Masereeuw R: Biomarker discovery with SELDI-TOF MS in human urine associated with early renal injury: evaluation with computational analytical tools. Nephrol Dial Transplant 2007, 22(10):2932-2943.

28. Haubitz M, Wittke S, Weissinger EM, Walden M, Rupprecht HD, Floege J, Haller $\mathrm{H}$, Mischak $\mathrm{H}$ : Urine protein patterns can serve as diagnostic tools in patients with IgA nephropathy. Kidney Int 2005, 67(6):2313-2320.

29. Julian BA, Wittke S, Haubitz M, Zurbig P, Schiffer E, McGuire BM, Wyatt RJ, Novak J: Urinary biomarkers of IgA nephropathy and other IgAassociated renal diseases. World J Urol 2007, 25(5):467-476.

30. Weissinger EM, Wittke S, Kaiser T, Haller H, Bartel S, Krebs R, Golovko I, Rupprecht HD, Haubitz M, Hecker H, Mischak H, Fliser D: Proteomic patterns established with capillary electrophoresis and mass spectrometry for diagnostic purposes. Kidney Int 2004, 65(6):2426-2434

31. Xu BJ, Shyr Y, Liang X, Ma LJ, Donnert EM, Roberts JD, Zhang X, Kon V, Brown NJ, Caprioli RM, Fogo AB: Proteomic patterns and prediction of glomerulosclerosis and its mechanisms. J Am Soc Nephrol 2005, 16(10):2967-2975

32. Rossing K, Mischak H, Dakna M, Zurbig P, Novak J, Julian BA, Good DM, Coon JJ, Tarnow L, Rossing P: Urinary proteomics in diabetes and CKD. J Am Soc Nephrol 2008, 19(7):1283-1290.

33. Papale M, Di Paolo S, Magistroni R, Lamacchia O, Di Palma AM, De Mattia A, Rocchetti MT, Furci L, Pasquali S, De Cosmo S, Cignarelli M, Gesualdo L: Urine proteome analysis may allow noninvasive differential diagnosis of diabetic nephropathy. Diabetes Care 2010, 33(11):2409-2415.

34. Lapolla A, Molin L, Seraglia R, Sechi A, Cosma C, Bonfante L, Chilelli NC, Ragazzi $E$, Traldi P: Urinary peptides as a diagnostic tool for renal failure detected by matrix-assisted laser desorption/ionisation mass spectrometry: an evaluation of their clinical significance. Eur J Mass Spectrom (Chichester, Eng) 2011, 17(3):245-253.

35. Lapolla A, Seraglia R, Molin L, Williams K, Cosma C, Reitano R, Sechi A, Ragazzi $E$, Traldi P: Low molecular weight proteins in urines from healthy subjects as well as diabetic, nephropathic and diabetic-nephropathic patients: a MALDI study. J Mass Spectrom 2009, 44(3):419-425.

36. Fiedler GM, Baumann S, Leichtle A, Oltmann A, Kase J, Thiery J, Ceglarek U: Standardized peptidome profiling of human urine by magnetic bead separation and matrix-assisted laser desorption/ionization time-of-flight mass spectrometry. Clin Chem 2007, 53(3):421-428.

37. Wu J, Wang N, Wang J, Xie Y, Li Y, Liang T, Wang J, Yin Z, He K, Chen X: Identification of a uromodulin fragment for diagnosis of $\lg \mathrm{A}$ nephropathy. Rapid Commun Mass Spectrom 2010, 24(14):1971-1978.

38. Navarro-Munoz M, Ibernon M, Bonet J, Perez V, Pastor MC, Bayes B, CasadoVela J, Navarro M, Ara J, Espinal A, Fluvia L, Serra A, Lopez D, Romero R: Uromodulin and alpha(1)-Antitrypsin Urinary Peptide Analysis to Differentiate Glomerular Kidney Diseases. Kidney Blood Press Res 2012, 35(5):314-325.

39. Perez V, Navarro-Munoz M, Mas S, Bayes B, Pastor MC, Martinez-Caceres E, Lauzurica R, Egido J, Romero R: Proteomic approach to the study of statin pleiotropy in kidney transplant patients. Pharmacology 2011, 87(3-4):161-168.

40. Kwak NJ, Wang EH, Heo IY, Jin DC, Cha JH, Lee KH, Yang CW, Kang CS, Choi $\mathrm{YJ}$ : Proteomic analysis of alpha-1-antitrypsin in immunoglobulin $\mathrm{A}$ nephropathy. Proteomics Clin Appl 2007, 1(4):420-428. 
41. Prajczer S, Heidenreich U, Pfaller W, Kotanko P, Lhotta K, Jennings P:

Evidence for a role of uromodulin in chronic kidney disease progression. Nephrol Dial Transplant 2010, 25(6):1896-1903.

42. Lhotta K: Uromodulin and chronic kidney disease. Kidney Blood Press Res 2010, 33(5):393-398.

43. Vyletal P, Bleyer AJ, Kmoch S: Uromodulin biology and pathophysiologyan update. Kidney Blood Press Res 2010, 33(6):456-475.

44. Tomita H, Sanford RB, Smithies O, Kakoki M: The kallikrein-kinin system in diabetic nephropathy. Kidney Int 2012, 81(8):733-744.

45. Pereira RL, Buscariollo BN, Correa-Costa M, Semedo P, Oliveira CD, Reis VO, Maquigussa E, Araujo RC, Braga TT, Soares MF, Moura IC, Malheiros DM,

Filho AP, Keller AC, Camara NO: Bradykinin receptor 1 activation exacerbates experimental focal and segmental glomerulosclerosis. Kidney Int 2011, 79(11):1217-1227.

doi:10.1186/1471-2369-14-82

Cite this article as: Graterol et al:: Poor histological lesions in IgA

nephropathy may be reflected in blood and urine peptide profiling. BMC Nephrology 2013 14:82.

\section{Submit your next manuscript to BioMed Central and take full advantage of:}

- Convenient online submission

- Thorough peer review

- No space constraints or color figure charges

- Immediate publication on acceptance

- Inclusion in PubMed, CAS, Scopus and Google Scholar

- Research which is freely available for redistribution 